\title{
Economic and mathematical modeling of industrial enterprise business model financial efficiency estimation
}

\author{
Mykola Havrylenko ${ }^{1}$, Vira Shiyko ${ }^{2}$, Liliana Horal $^{2}$, Inesa Khvostina ${ }^{3,}$, and Natalia Yashcheritsyna ${ }^{3}$ \\ ${ }^{1}$ PJSC "Ukrtransnafta", Kiyv, Ukraine \\ ${ }^{2}$ Ivano-Frankivsk National Technical University of Oil and Gas, Department of Finance, Ivano-Frankivsk, Ukraine \\ ${ }^{3}$ Ivano-Frankivsk National Technical University of Oil and Gas, Department of Economic, Ivano-Frankivsk, Ukraine
}

\begin{abstract}
The article proposes two methods for evaluating the financial efficiency of a business model of industrial enterprises. In order to evaluate the financial efficiency of the business model of an industrial enterprise, a system of single indicators for assessing the financial condition of the enterprise by such components as financial stability, liquidity and solvency, business activity and profitability was formed. Fishburne's rule weights the major components of an integral measure of an enterprise's business model financial performance. In addition, an integral measure of the financial performance of the business model is modeled using the fuzzy set method and taxonomic analysis, which will help to evaluate the financial performance level of the business model more objectively. The comparative analysis of the obtained results by different methods of calculation of integral indicators is carried out.
\end{abstract}

\section{Introduction}

An important issue in shaping the business model of an enterprise is the evaluation of its effectiveness, and especially of financial efficiency, which is a matter of principle for businesses focused on obtaining an economic effect.

Studying various scientific sources which cover problems of estimation of business models of enterprises $[1,2,3,4,5]$ we have concluded that in modern works there are many approaches to formation of modern business models of enterprises, but we are offered two approaches for evaluating the financial performance of an industrial enterprise business model, according to which it is proposed to use an integral measure of the economic efficiency of an enterprise business model using the Harrington desirability function and the taxon method endemy, in addition to a comparative analysis of the results of calculations for integrated parameter with both methods.

\section{Background}

Kayaoglu Nuri in dissertation [1] proposed hierarchical business model evaluation approach, on the one hand, acts as a skeleton for the businesses by providing a structured way of thinking; it provides a strong foundation for abstract level analysis of relations, gains, and faults that form the core of the businesses. On the other hand, the contributed concepts, evaluation model approach, and the evaluation tool, give us enough confidence to place this work as a contribution under strategic management in the management context. Deviating from the commonly used static methods, in this work, they propose a dynamic solution. The authors [2] elaborate a categorization of tools and methodologies concerning two major logics of evaluation: analytical/effectual and quantitative/qualitative. This sheds light upon the dominant mode of evaluation within different stages of digital BMI processes. A. Batocchio, A. Ghezzi and A. Rangone in their article [3] proposed method (roadmap for implementation of business models - RIBM) is composed of nine steps, and seven initials conditions (limitations). Such conditions reduce its complexity (e.g. performance management system is defined in the company). In the paper [4] author present the results of a review analysis on business model evaluation methods and their utility for entrepreneurs in developing and evaluating their business models. In addition, author indicate, there is a certain gap between the academic perspective to business models and the entrepreneur's perspective, there being an ever-growing need for practical and operational instruments.

Although there has been an important amount of research on business models, defining the business model concept, taxonomy of business models, decomposing business models and identifying their components, ontology and design tools; the research on business model is still an area that has not been sufficiently investigated.

\section{Methodology}

The financial performance of an industrial enterprise is evaluated by a comprehensive system of indicators of financial stability, liquidity and solvency, business activity and profitability. All these indicators are well

Corresponding author: inesa.hvostina@gmail.com 
known. However, in order to determine the overall assessment of financial performance, we propose to form an integral indicator of evaluating the financial performance of an enterprise business model.

Thus, the process of evaluating the financial performance of a business model of an industrial enterprise (fig. 1.)

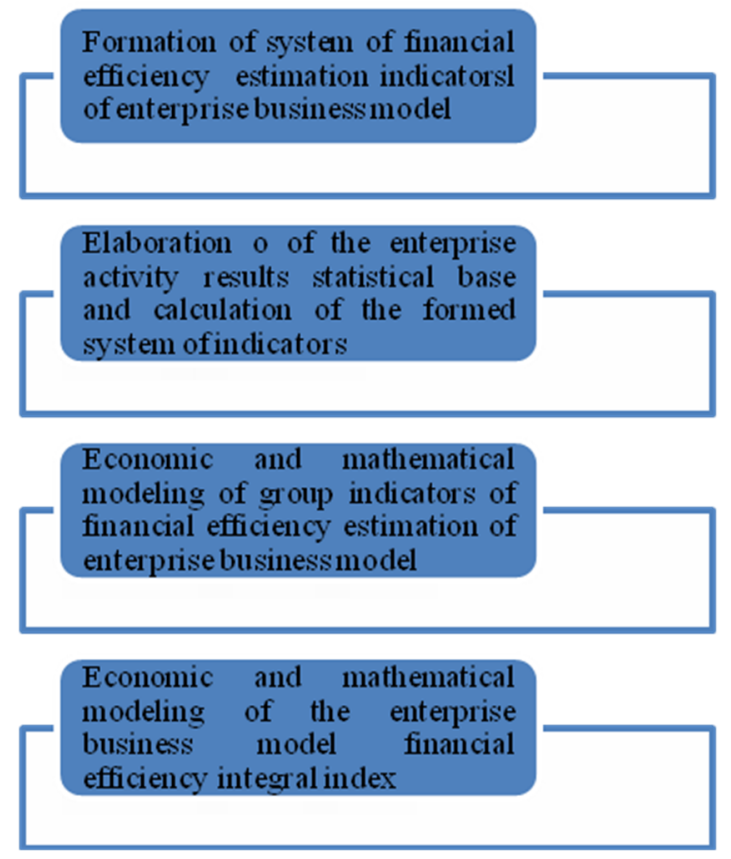

Fig. 1. The stages of economy and mathematical modelling of the enterprise business model financial efficiency integral index.

The financial performance of a business model of an industrial enterprise can be estimated on the basis of values of indicators values generalized groups:

$$
I_{f}=f\left(Y_{1} ; Y_{2} ; Y_{3} ; Y_{4}\right)
$$

where $Y_{i}$ is the corresponding $i$-th group of indicators.

Given that each value of $Y_{i}$ in model (1) is also an integral indicator of the evaluation of each of the evaluation directions, the given model is slightly modified.

$$
\begin{gathered}
Y_{i}=f\left(f_{1}\left(x_{1.1} ; x_{1.2} ; \ldots x_{1 . n}\right) ; f_{2}\left(x_{2.1} ; x_{2.2} ; \ldots x_{2 . m}\right) ;\right. \\
\left.f_{3}\left(x_{3.1} ; x_{3.2} ; \ldots x_{3 . l}\right) ; f_{4}\left(x_{4.1} ; x_{4.2} ; \ldots x_{4 . k}\right)\right)
\end{gathered}
$$

where $x_{1.1} ; x_{1.2} ; \ldots x_{1 . n}-$ single indicators of financial sustainability assessment;

$x_{2.1} ; x_{2.2} ; \ldots x_{2 . m}-$ single liquidity and solvency indicators;

$x_{3.1} ; x_{3.2} ; \ldots x_{3 . l}-$ single indicators of business activity evaluation;

$x_{4.1} ; x_{4.2} ; \ldots x_{4 . k}-$ single profitability metrics;

$f_{1}, f_{2}, f_{3}, f_{4}$ - integral indicators of each of an industrial enterprise business model identified component financial efficiency.

Table 1 summarizes the individual indicators for assessing the financial performance of a business model of an industrial enterprise.
Table 1. Indicators of selected components for economic and

\begin{tabular}{|c|c|c|}
\hline $\begin{array}{l}\text { The name of the } \\
\text { component }\end{array}$ & $\begin{array}{c}\text { The name of a single } \\
\text { metric }\end{array}$ & $\begin{array}{c}\text { The designation } \\
\text { used in the } \\
\text { model }\end{array}$ \\
\hline \multirow{13}{*}{$\begin{array}{l}\text { Component of } \\
\text { financial stability } \\
\qquad\left(f_{1}\right)\end{array}$} & $\begin{array}{l}\text { Financial independence } \\
\text { ratio }\end{array}$ & $x_{1.1}$ \\
\hline & $\begin{array}{c}\text { Financial dependency } \\
\text { ratio }\end{array}$ & $x_{1.2}$ \\
\hline & Financial Risk Ratio & $x_{1.3}$ \\
\hline & $\begin{array}{l}\text { Coefficient of financial } \\
\text { stability }\end{array}$ & $x_{1.4}$ \\
\hline & $\begin{array}{l}\text { Ratio of mobile and } \\
\text { immobilized assets }\end{array}$ & $x_{1.5}$ \\
\hline & \begin{tabular}{|c} 
Long-term commitment \\
ratio \\
\end{tabular} & $x_{1.6}$ \\
\hline & $\begin{array}{c}\text { Ratio of current } \\
\text { liabilities }\end{array}$ & $x_{1.7}$ \\
\hline & Financial leverage ratio & $x_{1.8}$ \\
\hline & $\begin{array}{l}\text { Maneuverability factor } \\
\text { of own }\end{array}$ & $x_{1.9}$ \\
\hline & $\begin{array}{l}\text { Coefficient of supply of } \\
\text { inventories with own } \\
\text { funds }\end{array}$ & $x_{1.10}$ \\
\hline & $\begin{array}{c}\text { Working capital } \\
\text { maneuverability factor }\end{array}$ & $x_{1.11}$ \\
\hline & Fixed Assets Index & $x_{1.12}$ \\
\hline & $\begin{array}{l}\text { The coefficient of the } \\
\text { real value of fixed assets }\end{array}$ & $x_{1.13}$ \\
\hline \multirow{6}{*}{$\begin{array}{l}\text { Solvency and } \\
\text { liquidity } \\
\text { component }\left(f_{2}\right)\end{array}$} & \begin{tabular}{|l|} 
Solvency ratio \\
\end{tabular} & $X 2.1$ \\
\hline & Absolute liquidity ratio & $X 2.2$ \\
\hline & Quick liquidity ratio & $X 2.3$ \\
\hline & Critical liquidity ratio & $X 2.4$ \\
\hline & Coefficient of coverage & $X 2.5$ \\
\hline & $\begin{array}{c}\text { Ratio of current and } \\
\text { total assets }\end{array}$ & $X 2.6$ \\
\hline \multirow{9}{*}{$\begin{array}{l}\text { Business activity } \\
\text { component }\left(f_{3}\right)\end{array}$} & $\begin{array}{c}\text { Ratio of total capital } \\
\text { turnover }\end{array}$ & $X 3.1$ \\
\hline & Mobile turnover rate & $X 3.2$ \\
\hline & $\begin{array}{c}\text { The turnover ratio of } \\
\text { tangible working capital }\end{array}$ & $X 3.3$ \\
\hline & $\begin{array}{c}\begin{array}{c}\text { Receivables turnover } \\
\text { ratio }\end{array} \\
\end{array}$ & $X 3.4$ \\
\hline & $\begin{array}{l}\text { The average term of } \\
\text { receivables turnover }\end{array}$ & $X 3.5$ \\
\hline & $\begin{array}{c}\text { Ratio of accounts } \\
\text { payable }\end{array}$ & $X 3.6$ \\
\hline & $\begin{array}{c}\text { The average term of } \\
\text { turnover of accounts } \\
\text { payable }\end{array}$ & $X 3.7$ \\
\hline & $\begin{array}{c}\text { Fund return on fixed } \\
\text { assets and other fixed } \\
\text { assets }\end{array}$ & $X 3.8$ \\
\hline & Equity turnover ratio & $\begin{array}{r}X 3.9 \\
\end{array}$ \\
\hline \multirow{5}{*}{$\begin{array}{l}\text { The profitability } \\
\text { component }\left(f_{4}\right)\end{array}$} & $\begin{array}{c}\text { The rate of return on } \\
\text { assets }\end{array}$ & $X 4.1$ \\
\hline & Return on equity ratio & $X 4.2$ \\
\hline & Return on Equity Ratio & $X 4.3$ \\
\hline & Profitability ratio & $X 4.4$ \\
\hline & $\begin{array}{c}\text { The profitability ratio of } \\
\text { products }\end{array}$ & $X 4.5$ \\
\hline
\end{tabular}
mathematical modeling of the integral indicator of the enterprise business model financial efficiency evaluation.

Next, it is necessary to calculate the significance of the factors. To do this, we use the Fishburn rule, which allows us to determine the level of significance of indicators 
based on their ranking. If you order the system of indicators according to the degree of their decrease, the significance of the $f_{i}$-th component should be determined by the formula (3):

$$
r_{i}=\frac{2(N-i+1)}{(N+1) N}
$$

where $r_{i}$ is the weighting factor of the $i$-th component; $N$ - the number of indicators of the population; $i$ - sequence number (rank) of the population index.

Investigating scientific works that raised the issues of ranking components of the financial performance of enterprises, it was found that the priority indicators that characterize the financial condition of the company are indicators of profitability and business activity beyond solvency and liquidity and recent financial stability. Table 2 shows the results of calculating the degree of significance of each of the components.

Table 2. Calculation of component constituents significance degrees and single indicators.

\begin{tabular}{|c|c|}
\hline The name of the component & $\begin{array}{c}\text { The specific weight } \\
\text { of the component }\end{array}$ \\
\hline The profitability component $\left(f_{4}\right)$ & 0,4 \\
\hline Business activity component $\left(f_{3}\right)$ & 0,3 \\
\hline Solvency and liquidity component $\left(f_{2}\right)$ & 0,2 \\
\hline Component of financial stability $\left(f_{1}\right)$ & 0,1 \\
\hline
\end{tabular}

Table 3 shows the estimated values of financial ratios for the company JSC Ukrtransnafta for 2014-2018 years.

It should be noted that when analyzing even some of the indices that characterize the financial efficiency of an industrial enterprise's business model, ambiguous situations are possible when, by these certain indicators, financial efficiency can acquire both positive and negative trends. Therefore, to solve this problem, we propose the use of methodology and mathematical apparatus of the theory of fuzzy sets.

The basis of the notion of fuzzy sets is the idea that the constituent elements of a given set, which have a common property, can possess this property to varying degrees (and to a different extent), and therefore belong to this set with different degrees [5]. Therefore, it is necessary to use a single universal generalized indicator.

However, if a business model's financial performance is assessed on the basis of several financial indicators, then it would be advisable to carry it out using some integral metric to construct a generalized Harrington function:

$$
\begin{gathered}
D=\sqrt[n]{\prod_{i=1}^{n} d_{i}} \\
\left.d_{i}=\exp (-\exp )\left(-y_{\mathrm{i}}\right)\right)
\end{gathered}
$$

where $n$ is the number of indicators used to evaluate the financial performance of a business model of an industrial enterprise;

$d_{i}-$ is a partial function that is defined according to the Harrington scale;

$y_{i}$ - a single measure of the financial performance of a business model of a business enterprise in dimensionless form.

\begin{tabular}{|c|c|c|c|c|c|}
\hline The name of a single metric & 2014 & 2015 & 2016 & 2017 & 2018 \\
\hline Financial independence ratio & 0,83 & 0,83 & 0,85 & 0,80 & 0,84 \\
\hline Financial dependency ratio & 0,17 & 0,17 & 0,15 & 0,20 & 0,16 \\
\hline Financial Risk Ratio & 0,20 & 0,20 & 0,17 & 0,25 & 0,19 \\
\hline $\begin{array}{l}\text { Coefficient of financial } \\
\text { stability }\end{array}$ & 5,06 & 4,96 & 5,75 & 4,06 & 5,34 \\
\hline $\begin{array}{l}\text { Ratio of mobile and } \\
\text { immobilized assets }\end{array}$ & 0,09 & 0,17 & 0,39 & 0,36 & 0,44 \\
\hline Long-term commitment ratio & 14,26 & 6,83 & 4,54 & 6,93 & 15,78 \\
\hline Ratio of current liabilities & 0,12 & 0,21 & 0,22 & 0,45 & 0,37 \\
\hline Financial leverage ratio & 2,82 & 1,38 & 0,79 & 1,70 & 2,96 \\
\hline $\begin{array}{c}\text { Maneuverability factor of } \\
\text { own }\end{array}$ & 0,10 & 0,17 & 0,33 & 0,33 & 0,36 \\
\hline $\begin{array}{l}\text { Coefficient of supply of } \\
\text { inventories with own funds }\end{array}$ & 18,53 & 33,42 & 2,82 & 2,58 & 2,19 \\
\hline $\begin{array}{c}\text { Working capital } \\
\text { maneuverability factor }\end{array}$ & 0,05 & 0,03 & 0,35 & 0,39 & 0,46 \\
\hline Fixed Assets Index & 1,10 & 1,03 & 0,84 & 0,91 & 0,83 \\
\hline $\begin{array}{l}\text { The coefficient of the real } \\
\text { value of fixed assets }\end{array}$ & 0,91 & 0,84 & 0,69 & 0,71 & 0,63 \\
\hline Solvency ratio & 0,87 & 1,31 & 4,63 & 1,69 & 0,96 \\
\hline Absolute liquidity ratio & 0,87 & 1,31 & 4,63 & 1,69 & 0,97 \\
\hline Quick liquidity ratio & 3,92 & 4,01 & 5,55 & 1,83 & 2,81 \\
\hline Critical liquidity ratio & 3,92 & 4,01 & 5,58 & 1,84 & 2,84 \\
\hline Coefficient of coverage & 4,15 & 4,14 & 8,65 & 3,01 & 5,22 \\
\hline $\begin{array}{c}\text { Ratio of current and total } \\
\text { assets }\end{array}$ & 0,08 & 0,14 & 0,28 & 0,27 & 0,31 \\
\hline Ratio of total capital turnover & 0,10 & 0,13 & 0,16 & 0,18 & 0,27 \\
\hline Mobile turnover rate & 1,13 & 0,94 & 0,58 & 0,69 & 0,89 \\
\hline $\begin{array}{c}\text { The turnover ratio of tangible } \\
\text { working capital }\end{array}$ & 20,92 & 31,30 & 1,62 & 1,77 & 1,95 \\
\hline Receivables turnover ratio & 8,00 & 20,77 & 20,73 & 15,47 & 53,11 \\
\hline $\begin{array}{l}\text { The average term of } \\
\text { receivables turnover }\end{array}$ & 45,65 & 17,57 & 17,61 & 23,60 & 6,87 \\
\hline Ratio of accounts payable & 4,68 & 3,87 & 4,97 & 2,07 & 4,66 \\
\hline $\begin{array}{c}\text { The average term of turnover } \\
\text { of accounts payable }\end{array}$ & 77,96 & 94,20 & 73,39 & 176,49 & 78,38 \\
\hline $\begin{array}{c}\text { Fund return on fixed assets } \\
\text { and other fixed assets }\end{array}$ & 0,10 & 0,16 & 0,22 & 0,25 & 0,39 \\
\hline Equity turnover ratio & 0,11 & 0,16 & 0,19 & 0,23 & 0,32 \\
\hline The rate of return on assets & 0,03 & 0,06 & 0,07 & 0,10 & 0,10 \\
\hline Return on equity ratio & 0,03 & 0,07 & 0,08 & 0,13 & 0,12 \\
\hline Return on Equity Ratio & 1,50 & 2,96 & 3,30 & 4,65 & 3,18 \\
\hline Profitability ratio & 0,29 & 0,69 & 0,66 & 0,64 & 0,43 \\
\hline $\begin{array}{l}\text { The profitability ratio of } \\
\text { products }\end{array}$ & 0,21 & 0,59 & 0,43 & 0,55 & 0,39 \\
\hline
\end{tabular}

Table 3. Estimated values of financial ratios for the company JSC Ukrtransnafta for 2014-2018 years [8].

Harrington's generalized function is a quantitative, unambiguous, single, and universal measure of the quality of an object under study, and if you add such qualities as adequacy, efficiency, and statistical sensitivity, it becomes clear that it can be used as an optimization criterion.

The Harrington scale is conventionally divided into five sections, which characterize the dimensionless dimensions of the indicators under consideration. To apply the Harrington scale, all the studied parameters must be dimensionless in accordance with the abscissa and calculate the values of the partial functions of Harrington by equation (4). The number of partial functions obtained equals the number of indicators of evaluating the financial efficiency of an industrial 
enterprise's business model.

The following is a generalized measure of performance, based on the values of the function $d_{i}$ by the formula

In the course of the research, certain simplifications were made in the integral assessment of the financial efficiency of an industrial enterprise's business model based on a fuzzy multiple analysis $[5,6,7]$ :

1. The fuzzy multiple approach was implemented only for quantification, in particular when calculating key financial ratios.

2. The choice of financial analysis ratios is not straightforward. Therefore, the proposed calculation method will also work with the use of other financial indicators.

3. The financial statements of the enterprises were selected from open sources of information which we believe to be fairly reliable.

4. The financial analysis was carried out without taking into account the factors of inflation, seasonality, etc.

Analysis of financial statements of industrial enterprises consists of the calculation of certain financial and economic indicators - ratios of liquidity and solvency, financial stability, profitability, business activity.

An important step in the process of analyzing the effectiveness of activity is the prediction of the integral indicator of financial efficiency business model of an industrial enterprise.

To determine the overall level of financial performance of a business model of an industrial enterprise, it is proposed to use some integral indicator, on the basis of which we can make a clear conclusion about the level of efficiency. The basis of such an indicator is the idea of transforming the natural values of each criterion for evaluating the financial efficiency of a business model of an industrial enterprise into a dimensionless form and further calculating the integral indicator. An integrated measure of the financial performance of an industrial enterprise business model (the Harrington generalized function is proposed as such) takes a value from 0 to 1 .

Since the desirability function of Harrington uses dimensionless financial performance of a business model in dimensionless form, it is necessary to carry out the normalization (standardization) of these indicators.

The procedure for standardization of indicators leads to elimination of measurement units and alignment of indicator values.

Using element multiplicity $\mathrm{w}$ described by n-signs, each unit can be interpreted as a point of $\mathrm{n}$-dimensional space with coordinates equal to the value of $\mathrm{n}$ attributes for the analysed unit. Let us represent the matrix as follows:

$$
X=\left[\begin{array}{l}
x_{11} x_{12} \ldots x_{1 k} \ldots x_{1 n} \\
x_{21} x_{22} \ldots x_{2 k} \ldots x_{2 n} \\
\ldots \ldots \ldots \ldots \ldots \ldots \ldots \ldots \\
x_{i 1} x_{i 2} \ldots x_{i k} \ldots x_{i n} \\
\ldots \ldots \ldots \ldots \ldots \ldots \ldots \\
x_{w 1} x_{w 2} \ldots x_{w k} \ldots x_{w n}
\end{array}\right]
$$

where: $w$ is the number of study periods, $\mathrm{n}$ is the number of indicators of each recreational forest management potential, $x_{i k}-$ indicator value $k$ of each specific component for a year $(k=1 \div n, i=1 \div w)$.

The differentiation of the observation matrix attributes is based on the study of each attribute impact on the level of recreational forest management potential, as well as the distribution of attributes by the positive (as a set of stimulants) and negative impact (a set of stimulants) on the recreational forest management potential. A high level of a certain attribute will determine a positive character, a low level will determine a negative character of the comparison attribute. This differentiation will make it possible to choose reference points in the variation of sustainability level indicators of land regulation [10].

An important step in the construction of integral performance indicators for the business model of an industrial enterprise is to normalize the various unit indices of the efficiency of using a set of components for this procedure, we will use a method of aggregating features based on the so-called theory of "additive value", according to which the value of the whole is equal to the value of the whole components. If the signs of the set have different units of measurement, then additive aggregation requires bringing them to one basis, that is, the previous normalization [8].

Normalization for constructing an integral metric constructed using the Harrington function is carried out by the formulas:

for "higher the better" metrics:

$$
z_{i k}=\frac{x_{i k}-x_{\min }}{x_{\max }-x_{\min }}
$$

for "less is better" metrics:

$$
z_{i k}=\frac{x_{\max }-x_{i k}}{x_{\max }-x_{\min }}
$$

where: $z_{i k}$ - normalization indicator $k$, in period $i$; $x_{i k}$ - indicator $k$, in period $i$ before normalization; $x_{\min }-$ minimum indicator $k$, in period $i$ before normalization;

$x_{\max }-$ maximum indicator $k$, in period $i$ before normalization.

The task of normalization of indicators is the transition to such a scale of measurements, when the "best" value of the indicator corresponds to the value 1 and the "worst" the value 0 . From the point of view of mathematics, it is the task of normalizing variables, and in terms of statistics - the transition from absolute to normalized values of indicators that vary from 0 to 1 and already by their magnitude characterize the degree of approximation to the optimum value, which can also be interpreted in percentage: 0 corresponds to $0 \%, 1$ to $100 \%$ [9].

Table 3 shows the criterion parameters of the level of financial efficiency of a business model of an industrial enterprise.

This scale was chosen because it allowed several features to be combined with a single unit of measurement in the context of linguistic assessments. In doing so, it was possible to quantify on a dimensionless scale the level from completely unacceptable (0) to completely 
acceptable (1).

Table 4. Critical parameters of the level of financial efficiency of an industrial enterprise's business model.

\begin{tabular}{|c|c|c|}
\hline $\begin{array}{c}\text { The level of financial efficiency } \\
\text { of a business model of an } \\
\text { industrial enterprise }\end{array}$ & $\begin{array}{c}\text { Numerical } \\
\text { values }\end{array}$ & $\begin{array}{c}\text { Potential } \\
\text { reserve (\%) }\end{array}$ \\
\hline Very high & $0,8-1$ & $0-20$ \\
\hline High & $0,64-0,8$ & $20-36$ \\
\hline Average & $0,37-0,64$ & $36-63$ \\
\hline Low & $0,2-0,37$ & $63-80$ \\
\hline Very low & $0,0-0,2$ & $80-100$ \\
\hline
\end{tabular}

As a result of observation matrix standardization, we obtain the following matrix:

$$
Z=\left[\begin{array}{l}
Z_{11} z_{12} \ldots z_{1 k} \ldots z_{1 n} \\
z_{21} z_{22} \ldots z_{2 k} \ldots z_{2 n} \\
\ldots \ldots \ldots \ldots \ldots \ldots \ldots \ldots \\
z_{i 1} z_{i 2} \ldots z_{i k} \ldots z_{i n} \\
\ldots \ldots \ldots \ldots \ldots \ldots \ldots \\
z_{w 1} z_{w 2} \ldots \ldots z_{w k} \ldots z_{w n}
\end{array}\right]
$$

Table 5 shows the results of standardization individual indicators.

Table 6 summarizes the calculations of the integral indicators of each of the components of the financial efficiency of an industrial enterprise's business model.

Figure 2 shows the dynamics of the integrated financial performance indicator of a business model of an industrial enterprise calculated using the Harrington function for 2014-2017.

In order to formulate clear conclusions about the level of financial efficiency of the business model of the enterprise, we propose to calculate another integral indicator using a taxonomic method, and to carry out standardization based on the determination of deviations of individual indicators from their average value.

For this stage, we use a taxonomic method based on determination of taxonomic indicators of each component. The determination of taxonomic indicators begins with identification of elements of observation matrix $X$, its elements are represented by indicator values expressed in units, specific for each indicator. The standardization shall be performed. The procedure for standardization of indicators leads to elimination of measurement units and alignment of indicator values.

The differentiation of the observation matrix attributes is based on the study of each attribute impact on the level of recreational forest management potential, as well as the distribution of attributes by the positive (as a set of stimulants) and negative impact (a set of stimulants). A high level of a certain attribute will determine a positive character, a low level will determine a negative character of the comparison attribute. This differentiation will make it possible to choose reference points in the variation of sustainability level indicators of land regulation [10].

The attributes are standardized according to the formula:

$$
z_{i k}=\frac{x_{i k}-\overline{x_{k}}}{s_{k}}
$$

Table 5. Standardized unit financial performance indicators of

\begin{tabular}{|c|c|c|c|c|c|}
\hline The name of a single metric & 2014 & 2015 & 2016 & 2017 & 2018 \\
\hline Financial independence ratio & 0,58 & 0,58 & 0,69 & 0,37 & 0,64 \\
\hline Financial dependency ratio & 0,58 & 0,58 & 0,69 & 0,37 & 0,64 \\
\hline Financial Risk Ratio & 0,59 & 0,59 & 0,69 & 0,37 & 0,62 \\
\hline Coefficient of financial stability & 0,58 & 0,56 & 0,69 & 0,37 & 0,63 \\
\hline $\begin{array}{l}\text { Ratio of mobile and immobilized } \\
\text { assets }\end{array}$ & 0,37 & 0,45 & 0,65 & 0,63 & 0,69 \\
\hline Long-term commitment ratio & 0,42 & 0,64 & 0,69 & 0,63 & 0,37 \\
\hline Ratio of current liabilities & 0,69 & 0,62 & 0,61 & 0,37 & 0,46 \\
\hline Financial leverage ratio & 0,39 & 0,62 & 0,69 & 0,57 & 0,37 \\
\hline Maneuverability factor of own & 0,37 & 0,47 & 0,66 & 0,66 & 0,69 \\
\hline $\begin{array}{l}\text { Coefficient of supply of } \\
\text { inventories with own funds }\end{array}$ & 0,55 & 0,69 & 0,38 & 0,37 & 0,37 \\
\hline $\begin{array}{l}\text { Working capital maneuverability } \\
\text { factor }\end{array}$ & 0,38 & 0,37 & 0,62 & 0,65 & 0,69 \\
\hline Fixed Assets Index & 0,37 & 0,46 & 0,68 & 0,61 & 0,69 \\
\hline $\begin{array}{l}\text { The coefficient of the real value } \\
\text { of fixed assets }\end{array}$ & 0,69 & 0,62 & 0,45 & 0,47 & 0,37 \\
\hline Solvency ratio & 0,37 & 0,41 & 0,69 & 0,45 & 0,38 \\
\hline Absolute liquidity ratio & 0,37 & 0,41 & 0,69 & 0,45 & 0,38 \\
\hline Quick liquidity ratio & 0,57 & 0,57 & 0,69 & 0,37 & 0,46 \\
\hline Critical liquidity ratio & 0,56 & 0,57 & 0,69 & 0,37 & 0,47 \\
\hline Coefficient of coverage & 0,44 & 0,44 & 0,69 & 0,37 & 0,51 \\
\hline Ratio of current and total assets & 0,37 & 0,46 & 0,66 & 0,65 & 0,69 \\
\hline Ratio of total capital turnover & 0,37 & 0,43 & 0,50 & 0,54 & 0,69 \\
\hline Mobile turnover rate & 0,69 & 0,59 & 0,37 & 0,44 & 0,57 \\
\hline $\begin{array}{l}\text { The turnover ratio of tangible } \\
\text { working capital }\end{array}$ & 0,59 & 0,69 & 0,37 & 0,37 & 0,37 \\
\hline Receivables turnover ratio & 0,37 & 0,47 & 0,47 & 0,43 & 0,69 \\
\hline $\begin{array}{c}\text { The average term of receivables } \\
\text { turnover }\end{array}$ & 0,37 & 0,62 & 0,62 & 0,57 & 0,69 \\
\hline Ratio of accounts payable & 0,67 & 0,58 & 0,69 & 0,37 & 0,66 \\
\hline $\begin{array}{l}\text { The average term of turnover of } \\
\text { accounts payable }\end{array}$ & 0,68 & 0,64 & 0,69 & 0,37 & 0,68 \\
\hline $\begin{array}{c}\text { Fund return on fixed assets and } \\
\text { other fixed assets }\end{array}$ & 0,37 & 0,44 & 0,52 & 0,55 & 0,69 \\
\hline Equity turnover ratio & 0,37 & 0,45 & 0,50 & 0,57 & 0,69 \\
\hline The rate of return on assets & 0,37 & 0,52 & 0,57 & 0,69 & 0,69 \\
\hline Return on equity ratio & 0,37 & 0,51 & 0,55 & 0,69 & 0,67 \\
\hline Return on Equity Ratio & 0,37 & 0,53 & 0,57 & 0,69 & 0,56 \\
\hline Profitability ratio & 0,37 & 0,69 & 0,67 & 0,66 & 0,49 \\
\hline The profitability ratio of products & 0,37 & 0,69 & 0,57 & 0,66 & 0,54 \\
\hline
\end{tabular}
an industrial enterprise's business model.

Table 6. Integral indicators of financial performance components of an industrial enterprise business model.

\begin{tabular}{|c|c|c|c|c|c|c|}
\hline $\begin{array}{c}\text { Components of } \\
\text { financial } \\
\text { efficiency of an } \\
\text { industrial } \\
\text { business model }\end{array}$ & $\begin{array}{c}\text { Specific } \\
\text { gravity } \\
\text { components }\end{array}$ & $\mathbf{2 0 1 4}$ & $\mathbf{2 0 1 5}$ & $\mathbf{2 0 1 6}$ & $\mathbf{2 0 1 7}$ & $\mathbf{2 0 1 8}$ \\
\hline $\begin{array}{c}\text { Component of } \\
\text { financial stability } \\
\left(f_{1}\right)\end{array}$ & 0,1 & 0,49 & 0,55 & 0,62 & 0,48 & 0,54 \\
\hline $\begin{array}{c}\text { Solvency and } \\
\text { liquidity } \\
\text { component }\left(f_{2}\right)\end{array}$ & 0,2 & 0,44 & 0,47 & 0,69 & 0,43 & 0,47 \\
\hline $\begin{array}{c}\text { Business activity } \\
\text { component }\left(f_{3}\right)\end{array}$ & 0,3 & 0,48 & 0,54 & 0,51 & 0,46 & 0,63 \\
\hline $\begin{array}{c}\text { The profitability } \\
\text { component }\left(f_{4}\right)\end{array}$ & 0,4 & 0,37 & 0,58 & 0,58 & 0,68 & 0,58 \\
\hline $\begin{array}{c}\text { Integral indicator of financial } \\
\text { efficiency of business model of } \\
\text { industrial enterprise }\end{array}$ & 0,43 & 0,55 & 0,59 & 0,54 & 0,57 \\
\hline
\end{tabular}




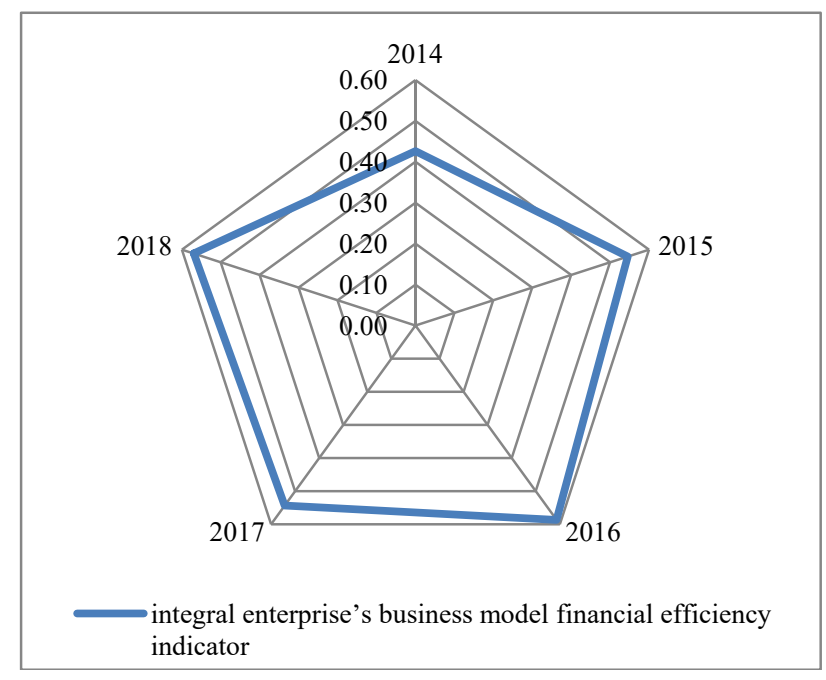

Fig. 2. The dynamics of the integrated financial performance indicator of a business model of an industrial enterprise calculated using the Harrington function for 2014-2017.

when

$$
\begin{gathered}
\overline{x_{k}}=\frac{1}{w} \sum_{i=1}^{w} x_{i k} \\
S_{k}=\sqrt{\frac{1}{w} \sum_{i=1}^{w}\left(x_{i k}-\overline{x_{k}}\right)^{2}}
\end{gathered}
$$

where: $z_{i k}$-standardized value of indicator $k$ for the $i$-th study period; $x_{i k}-$ standardized value of indicator $k$ for the $i$-th study period; $x_{k}$ - arithmetic mean of $k$ indicator; $S_{k}-$ standard deviation of $\mathrm{k}$ indicator; $w$-a number of periods.

By multiplying values of each standardized attributes by the hierarchy coefficient, corrected values of the corresponding attribute are used for taxonomic analysis.

The next step is the problem analysis of observation matrix differentiation. All variables are divided into stimulants and disincentives. The indicators of each component are divided into two groups based on the impact character of each of them on recreational forest management potential. Indicators, having a positive effect on recreational forest management potential, are considered stimulants, in contrast to the negative indicators, having a negative effect - the stimulants and, thus, reducing the level of recreational forest management potential [11].

Distribution of indicators into stimulants and disincentives serves as the basis to develop the so-called standard, represented by point $\mathbf{P}_{\mathbf{0}}$ with coordinates: $z_{01}$, $z_{02}, \ldots, z_{0 n}$ :

$$
\begin{aligned}
& z_{0 s}=\max z_{r s}, \text { if } s \in I \\
& z_{0 s}=\min z_{r s}, \text { if } s \notin I(s=1,2 \ldots n)
\end{aligned}
$$

where: $I$ is a set of stimulants, $z_{r s}$ is a standardized value of the exponent $\mathrm{s}$ of a specific block of costs for period $\mathrm{r}$. The distance between individual unit points and point $\mathbf{P}_{\mathbf{0}}$, representing the standard of cost level, is expressed as $C_{i 0}$ and calculate as follows:

$$
C_{i 0}=\left[\sum_{s=1}^{n}\left(z_{i s}-z_{0 s}\right)^{2}\right]^{\frac{1}{2}} \quad(i=1, \ldots \ldots, w)
$$

The obtained distances are considered as initial values used to calculate the indicator of recreational forest management potential:

$$
\begin{gathered}
d_{i}=1-\frac{c_{i 0}}{c_{0}} \\
-c_{0}=\frac{1}{w} \sum_{i=1}^{w} c_{i 0} \\
S_{0}=\left[\frac{1}{w} \sum_{i=1}^{w}\left(c_{i 0}-\bar{c}_{0}\right)^{2}\right]^{\frac{1}{2}}
\end{gathered}
$$

This indicator is interpreted as follows: it assumes a high value at high stimulus values and a low value at low stimulus values. The closer the figure is to one, the higher the level of recreational forest management potential. The indicator can serve for statistical characterises of elements infinity. It is possible to estimate the "average" level of the indicators, achieved within a certain period of time characterizing the analysed problem [12].

The results of the taxonomic analysis are summarized in table 7.

Table 7. Integral indicators of the financial performance components of an industrial enterprise business model are calculated using the taxonomy method.

\begin{tabular}{|c|c|c|c|c|c|c|}
\hline $\begin{array}{c}\text { Components of } \\
\text { financial } \\
\text { efficiency of an } \\
\text { industrial } \\
\text { business model }\end{array}$ & $\begin{array}{c}\text { Specific } \\
\text { gravity } \\
\text { components }\end{array}$ & $\mathbf{2 0 1 4}$ & $\mathbf{2 0 1 5}$ & $\mathbf{2 0 1 6}$ & $\mathbf{2 0 1 7}$ & $\mathbf{2 0 1 8}$ \\
\hline $\begin{array}{c}\text { Component of } \\
\text { financial stability } \\
\left(f_{1}\right)\end{array}$ & 0,1 & 0,22 & 0,41 & 0,59 & 0,10 & 0,32 \\
\hline $\begin{array}{c}\text { Solvency and } \\
\text { liquidity } \\
\text { component }\left(f_{2}\right)\end{array}$ & 0,2 & 0,17 & 0,34 & 0,48 & 0,08 & 0,36 \\
\hline $\begin{array}{c}\text { Business activity } \\
\text { component }\left(f_{3}\right)\end{array}$ & 0,3 & 0,26 & 0,46 & 0,35 & 0,10 & 0,63 \\
\hline $\begin{array}{c}\text { The profitability } \\
\text { component }\left(f_{4}\right)\end{array}$ & 0,4 & 0,06 & 0,58 & 0,62 & 0,93 & 0,60 \\
\hline $\begin{array}{c}\text { Integral indicator of financial } \\
\text { efficiency of business model of } \\
\text { industrial enterprise }\end{array}$ & 0,43 & 0,16 & 0,48 & 0,51 & 0,43 \\
\hline
\end{tabular}

Figure 3 shows the dynamics of the integral indicator of financial efficiency of a business model of an industrial enterprise calculated using the taxonomy method for 2014-2017.

\section{Results}

Thus, from the obtained results of the calculations, we can conclude unequivocally that during the analyzed period the financial efficiency of the business model of the studied enterprise is at an average level, and it should be noted a positive trend of growth of these indicators at the end of the period relative to the base period of the study. The increase in the financial performance indicator of Ukrtransnafta's business model has gone from 0,43 (43\%) in 2014 to $0,57(57 \%)$ in 2018 by an indicator calculated using the Harrington function and from $0,16(16 \%)$ in 2014 to $0,53(53 \%)$ in 2018 according to the taxonomic method. The growth of the integral indicator was largely due to the increase in the level of profitability of the 
enterprise, which show us the integral indicators of the profitability components in Tables 6 and 7. Such results were obtained as a result of the increase of profit of the enterprise from 688,689 thousand UAH in 2014 to 1463,239 thousand UAH. at the end of the analyzed period, which led to an increase in the level of individual profitability indicators.

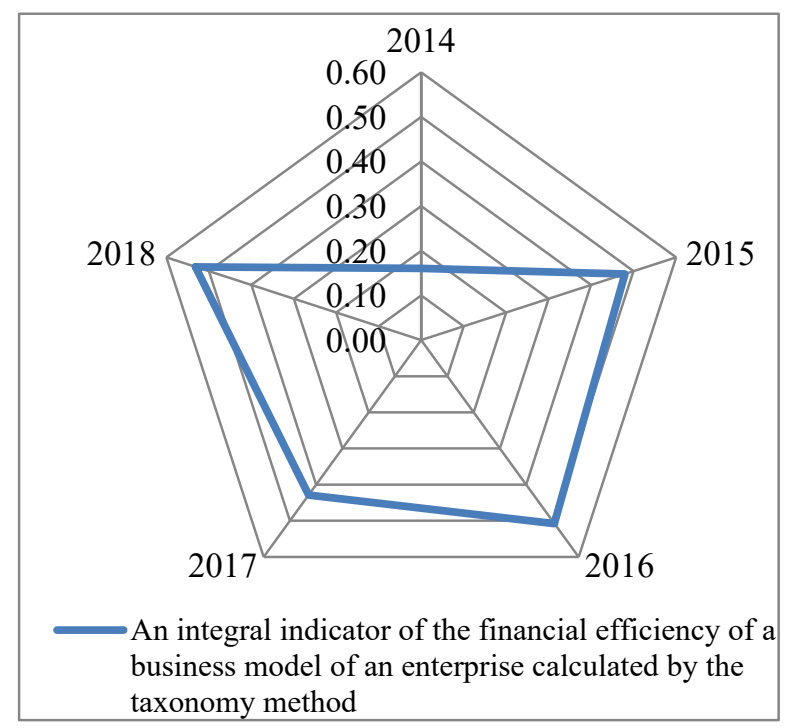

Fig. 3. The dynamics of the integral indicator of financial efficiency of a business model of an industrial enterprise calculated using the taxonomy method for 2014-2017.

Therefore, the interpretation of the calculated integral indicators of the financial performance of an industrial enterprise business model is as follows: it assumes high value at high values of stimulants and low value - at small values of stimulants (which clearly show us the results of calculations in Tables 6 and 7). The closer the index is to one, the higher the level of financial efficiency of the business model of the enterprise. An indicator of the financial performance level of an industrial enterprise's business model can serve as a statistical characteristic of many elements. It is possible to estimate the "average" level of the indicators that characterize the problem, achieved in some period of time.

The results of the study indicate that both methods of calculation indicate the same tendency of change of integral index of financial efficiency of business model of industrial enterprise and confirm the possibility of application of Harrington function and taxonomic analysis in construction of integral index of financial efficiency of business model of industrial enterprise that fully reflects the adequacy of the operation of an industrial enterprise under the influence of various factors.

\section{References}

1. K. Nuri, Dissertation, Technische Universität Berlin, 2014

2. J.F. Tesch, A.S. Brillinger, in Business Model Innovation in the Era of the Internet of Things, ed. by J.F. Tesch (Springer, Cham, 2019), pp. 67-86
3. A. Batocchio, A. Ghezzi, A. Rangone, A method for evaluating business models implementation process. J. Bus. Proc. Manag. 22, 712-735 (2016). doi:10.1108/BPMJ-08-2015-0117

4. M. Alexa, Business Model Evaluation - A Conceptual Approach. Rev. of Econ. and Busn. Stud. 14 (2014)

5. L. Horal, V. Shyiko, O. Yaroshenko, Modeling break-even zone using the integral methods. Paper presented at the 6th International conference on strategies, models and technologies of economic systems management, Ivano-Frankivsk National Technical University of Oil and Gas, Bukovel, 24-25 October 2019

6. V.Ie. Bakhrushyn, Methods of data analysis (KPU, Zaporizhzhia, 2011), pp. 157-191

7. V. Pliuta, Comparative multivariate analysis in economic research: taxonomy and factor analysis methods (Statystyka, Moskva 1980), p. 151

8. Official site PJSC "Ukrtransnafta", http:/www.ukrtransnafta.com. Accessed 25 Feb 2020

9. P. Velardi, A. Cucchiarelli, M. Petit, A taxonomy learning method and its application to characterize a scientific web community. IEEE transact. on know. and date engineer. 19(2), 180-191 (2007). doi:10.1109/TKDE.2007.21

10. A. Maedche, V. Pekar, S. Staab, in Web Intelligence, ed. by N. Zhong, J. Liu, Y. Yao (Springer, Berlin, Heidelberg, 2002), pp. 301-319

11. D. Zhang, W.S. Lee, Web taxonomy integration through co-bootstrapping. Paper presented at the 27th annual international ACM SIGIR conference on research and development in information retrieval, University of Sheffield, UK, 25-29 July, 2004

12. P. Cimiano, A. Hotho, S. Staab, Comparing conceptual, divisive and agglomerative clustering for learning taxonomies from text. Paper presented at the 16th ECAI, Artificial Intelligence Research Institute, Valencia, Spain, 22-27 August 2004 